\title{
Vulnerability and policy responses in the face of natural resource discoveries and climate change: introduction-CORRIGENDUM
}

\author{
John Cockburn, Martin Henseler, Hélène Maisonnave and Luca Tiberti \\ https://doi.org/10.1017/S1355770X18000347 Published online by Cambridge University Press, 30 July \\ 2018
}

Keywords: Developing countries, economic growth, natural resources, resource curse, corrigendum

The original version of this article incorrectly listed it as a Research Article rather than as an Introduction, an error for which we would like to apologise. It is in fact the introduction to our Special Issue on Natural Resources and Economic Development. A footnote has been added to the article in question reflecting this correction.

Similarly, we have updated the cover and table of contents for Volume 23, Issue 5 to reflect the contributions of the guest editors, John Cockburn, Hélène Maisonnave and Luca Tiberti.

\section{Reference}

Cockburn J, Henseler M, Maisonnave H, and Tiberti L (2018) Vulnerability and Policy Responses in the Face of Natural Resource Discoveries and Climate Change: Introduction. Environment and Development Economics 23(5), 517-526. doi:10.1017/S1355770X18000347. 